\title{
COMPARATIVE BIOEQUIVALENCE STUDIES OF CINNARIZINE AND ITS DIFFERENT AVAILABLE MARKETED FORMULATION DRUGS
}

\author{
SANJEEV KUMAR ${ }^{1}$, AMIN MIR M ${ }^{2 *}$, SARVESH KUMAR ${ }^{3}$, ANUJ KUMAR ${ }^{4}$
}

${ }^{1}$ Department of Pharmacy, Meerut Institute of Technology, Meerut, Uttar Pradesh, India. ${ }^{2}$ Department of Mathematics and Natural Sciences, Prince Mohammad Bin Fahd University, Al Khobar, Kingdom of Saudi Arabia. ${ }^{3}$ Department of Pharmaceutical Sciences, Hemvati Nandan Bahuguna Garhwal University, Srinagar, Uttarakhand, India. ${ }^{4}$ Department of Chemistry, Government PG College, Kotdwar, Uttarakhand, India. Email: mohdaminmir@gmail.com

Received: 09 March 2020, Revised and Accepted: 14 May 2020

\section{ABSTRACT}

Objective: The main focus of the study was to investigate the marketed formulations of cinnarizine and it is marketed analogous.

Methods: The study involved the analysis of basic pre-formulation studies, namely, physical properties, melting point, Fourier-transform infrared, loss on drying, assay of cinnarizine, standard curve, and partition co-efficient of various marketed tablets of cinnarizine.

Results: Cinnarizine is an H1-receptor antagonist drug which is widely used for the treatment of dynamical sickness, vomiting, and vertigo. In this study, five known marketed formulations of cinnarizine were evaluated for weight variation, hardness, drug content, friability, disintegration time, and in vitro dissolution as well as the drug release kinetics of the tablets. As per the study, the drugs show low disintegration time and good hardness, also in vitro dissolution studies have shown near about $90 \%$ drug release at the end of the first 10 min and then cumulative drug release of not less than $92 \%$ in the nearby 10 min. Hence, these formulations show lower friability, acceptable taste, and shorter disintegration time which make them suitable to be accepted. Thus, the tablets are good for the use, so allow them to be marketed for the wellbeing of humans.

Conclusion: It had been found that all the tablets show acceptable limits for various parameters of analysis, in a sustained manner. Thus, all the tablets are effective for usage under standard conditions.

Keywords: Antihistamine, Cinnarizine, Bioequivalence, Vertigo, Vomiting.

(c) 2020 The Authors. Published by Innovare Academic Sciences Pvt Ltd. This is an open access article under the CC BY license (http://creativecommons. org/licenses/by/4. 0/) DOI: http://dx.doi.org/10.22159/ajpcr.2020.v13i6.37384

\section{INTRODUCTION}

The delivery of drugs to the human body can be carried out through several routes such as oral topical, transdermal, and parenteral administration [1]. Among these, the oral ingestion is the predominant and most preferable route for drug delivery, as the oral system has the obvious advantage of the ease of administration and patient acceptance [2]. There are also many obvious reasons but also due to the fact that there is more flexibility in dosage design since constraints such as sterility and potential damage at the site of administration are minimized.

If a new product is intended to be as a substitute for an approved medicinal product as a pharmaceutical equivalent, the equivalence with this product should be justified like bioequivalent [3]. To ensure the clinical performance of such drug products, bioequivalence studies are conducted. Bioequivalence studies are conducted if there, whether there is a risk of bioequivalence or risk of pharmacotherapeutic failure clinical safety $[4,5]$. Furthermore, bioequivalence study can be demonstrated either in vivo or in vitro.

\section{METHODS}

The following mentioned marketed drugs have been used for analysis. All the chemicals and the equipment were of analytical grade and sterilized before the experimentation. The following studies have been conducted as basic pre-formulation studies, namely, physical properties, melting point, Fourier-transform infrared (FTIR), loss on drying, assay of cinnarizine, standard curve, and partition coefficient.

\section{FTIR spectral studies of cinnarizine}

FTIR spectrum of cinnarizine was obtained by means of an FTIR spectrophotometer. The given sample of cinnarizine was prepared and scanning was done by Cary 360 FTIR Agilent Technologies (measurements were attempted with the accumulation of 8 scans and a resolution of $4 \mathrm{~cm}^{-1}$ over the range of $400-4000 \mathrm{~cm}^{-1}$ ).

\section{Loss on drying}

The loss on drying test is designed to measure the amount of water and volatile matters in a sample when the sample is dried under specified conditions. It should be NMT $0.5 \%$.

\section{Assay of cinnarizine}

The UV spectrophotometry has been used for structural validation of drug in the identification studies. The drug was dissolved in $\mathrm{pH} 5.8$ to produce $10 \mu \mathrm{g} / \mathrm{ml}$ solutions. This $10 \mu \mathrm{g} / \mathrm{ml}$ drug solution was scanned between 200 and $400 \mathrm{~nm}$ using the UV spectrophotometer (Cary $60 \mathrm{UV}$ visible Agilent Technologies).

\section{Solubility studies of drug}

The solubility of was determined in different solvents (e.g., distilled water, ethanol, and di-ethyl ether). A known amount of drug $(100 \mathrm{mg}$ ) was suspended in $10 \mathrm{ml}$ of different solvents in tightly closed test tubes. Excess amount of drug was added to different solvents until the solution became saturated and these tubes were shaken for $1 \mathrm{~h}$. The supernatant was then analyzed by UV spectrophotometer (Cary 60 UV-visible Spectrophotometer, Agilent Technologies) at 205.0 $\mathrm{nm}$ with appropriate dilutions. Three determinations were carried out for each sample to calculate the solubility of cinnarizine.

\section{Determination of partition coefficient}

Partition coefficient of a drug is a measure of its hydrophilicity. It can be defined as the ratio of unionized drug distributed between the organic and aqueous phase at equilibrium. For a drug delivery system, hydrophilicity/hydrophilic balance has shown to be a contributing 
factor for the rate and extent of drug absorption. The partition coefficient provides a means of characterizing lyophilic/hydrophilic nature of a drug. It is the measurement of drug hydrophilicity and its ability to cross the lipid bilayer cell membrane.

\section{Drug content uniformity [7]}

Twenty tablets from each batch were weighed accurately and powdered powder equivalent to $100 \mathrm{mg}$ cinnarizine was shaken with $100 \mathrm{ml}$ of $(0.1 \mathrm{~N}) \mathrm{HCl}$ in $100 \mathrm{ml}$ volumetric-flask and from this $1 \mathrm{ml}$ was pipette out and then dilute up to $100 \mathrm{ml}$. The resulting solution was filtered and

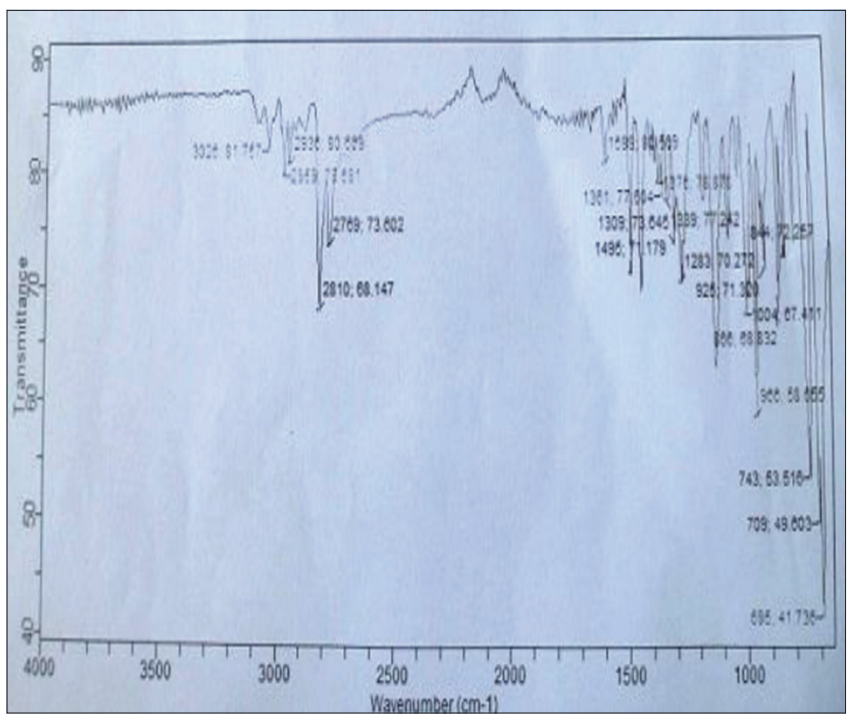

Fig. 1: Fourier-transform infrared spectral studies of cinnarizine

Table 1: Marketed formulation of cinnarizine [6]

\begin{tabular}{llll}
\hline S. No. & Brand name & Dosage form & Manufacturer \\
\hline 1. & Stugeron & Tablet $(25 \mathrm{mg})$ & Johnson and Johnson Ltd. \\
2. & Vertigon & Tablet $(25 \mathrm{mg})$ & Geno Pharmaceuticals Ltd. \\
3. & Cinzan & Tablet $(25 \mathrm{mg})$ & FDC Ltd. \\
4. & Sinarzine & Tablet $(25 \mathrm{mg})$ & Leeford Healthcare Ltd. \\
5. & Cinnifit & Tablet $(25 \mathrm{mg})$ & Galpha Laboratories Ltd. \\
\hline
\end{tabular}

Table 2: Melting point of cinnarizine

\begin{tabular}{ll}
\hline Melting point & \\
\hline Reported value & Observed value \\
\hline $117-120^{\circ} \mathrm{C}$ & $117^{\circ} \mathrm{C}$ \\
\hline
\end{tabular}

Table 3: Characteristic peaks of cinnarizine

\begin{tabular}{lll}
\hline Functional group & Range $\mathbf{c m}^{\mathbf{1}}$ & Drug $\mathbf{~ c m}^{\mathbf{- 1}}$ \\
\hline C-H & $3000-2700$ & 2810 \\
C=C & $1670-1580$ & 1599 \\
C-N & $1700-1600$ & 1699 \\
N-H & $3000-3700$ & 3028 \\
\hline
\end{tabular}

Table 4: Absorbance of cinnarizine at $205 \mathrm{~nm}$

\begin{tabular}{lll}
\hline S. No. & Concentration $(\boldsymbol{\mu g} / \mathbf{m l})$ & Absorbance $(\mathbf{m g} / \mathbf{m l})(\mathbf{2 0 5 . 0} \mathbf{~ n m})$ \\
\hline 1. & 0.2 & 0.0173 \\
2. & 0.4 & 0.0325 \\
3. & 0.6 & 0.0479 \\
4. & 0.8 & 0.0652 \\
5. & 1.0 & 0.0821 \\
\hline
\end{tabular}

assayed at $205 \mathrm{~nm}$ using UV/visible spectrometer and the content of different formulation of cinnarizine was calculated and the results are as.

\section{Determination of tablet hardness [7]}

Five tablets were sampled randomly selected from each batch and the hardness of the tablets was determined by the help of the Pfizer Hardness Tester $\left(\mathrm{kg} / \mathrm{cm}^{2}\right)$.

\section{Determination of friability of the tablet [7]}

This experiment is applicable to compressed tablets and is intended to determine the physical strength of tablets.

A maximum loss of weight (from a single test or from the mean of the three tests) not superior to $1.0 \%$ is acceptable for most tablets. If observably cracked, chipped, or broken tablets are present in the sample later than tumbling, the sample fails the test.

In vitro dissolution study [7]

The dissolution study was carried out in USP - II type dissolution apparatus (paddle type) in (Dissolution Test Apparatus [DS8000] LABINDIA). The dissolution study was performed at $50 \mathrm{rpm}$ in $900 \mathrm{ml}$ of simulated gastric fluid of $\mathrm{pH}$ 1.2. For tablets of cinnarizine, the dissolution media was $0.1 \mathrm{~N} \mathrm{HCl}$ which was prepared using $8.8 \mathrm{ml}$ of $35 \% \mathrm{HCl}$. The above-mentioned amount of acid is measured by measuring cylinder and then transfer it to $1000 \mathrm{ml}$ of volumetric flask and volume was made up to the mark with distilled water.

\section{OBSERVATIONS AND RESULTS}

Physical properties

- Color - crystalline white

- Odor - suspicious.

Table 5: Results are interpreted as

\begin{tabular}{ll}
\hline Solvents & Solubility \\
\hline Distilled water & Practically insoluble \\
Ethanol & Slightly soluble \\
Di-ethyl ether & Soluble \\
\hline
\end{tabular}

Table 6: Weight variation of the tablets

\begin{tabular}{lll}
\hline S. No. & Formulation & Weight variation $(\mathrm{g})$ \\
\hline 1. & Stugeron & $0.2455 \pm 0.02455$ \\
2. & Vertigon & $0.121 \pm 0.0121$ \\
3. & Cinzan & $0.176 \pm 0.0176$ \\
4. & Sinarzine & $0.187 \pm 0.0187$ \\
5. & Cinnifit & $0.205 \pm 0.0205$ \\
\hline
\end{tabular}

Table 7: Hardness of the tablets

\begin{tabular}{lll}
\hline S. No. & Formulation name & Hardness $\mathbf{( k g / \mathbf { c m } ^ { 2 } )}$ \\
\hline 1. & Stugeron & 2.0 \\
2. & Vertigon & 0.0 \\
3. & Cinzan & 4.0 \\
4. & Sinarzine & 0.8 \\
5. & Cinnifit & 0.2 \\
\hline
\end{tabular}

Table 8: Drug content of cinnarizine formulations

\begin{tabular}{lll}
\hline S. No. & Formulation name & Drug content (\%) \\
\hline 1. & Stugeron & 96.23 \\
2. & Vertigon & 99.54 \\
3. & Cinzan & 98.57 \\
4. & Sinarzine & 97.01 \\
5. & Cinnifit & 99.80 \\
\hline
\end{tabular}




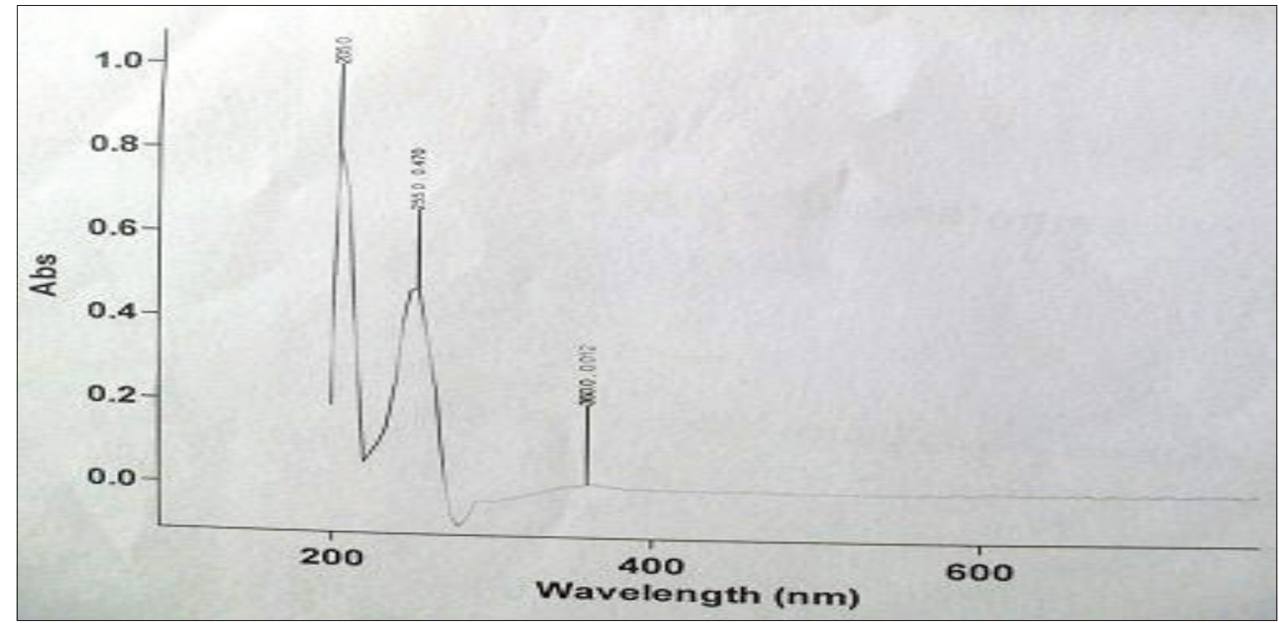

Fig. 2: UV-spectrophotometric curve $\left(\lambda_{\max }\right)$ of cinnarizine at $205 \mathrm{~nm}$

Table 9: In vitro dissolution study data for stugeron

\begin{tabular}{|c|c|c|c|c|c|c|}
\hline Time (min) & Absorbance (205 nm) & Conc. $(\mu \mathrm{g} / \mathrm{ml})$ & Amt. in $1 \mathrm{ml}$ & Amt. in $900 \mathrm{ml}$ & Cumulative release & $\%$ Cumulative drug release \\
\hline 0 & 0 & 0 & 0 & 0 & 0 & 0 \\
\hline 5 & 0.0224 & 2.7654 & 0.0027 & 2.4888 & 2.4888 & 9.9555 \\
\hline 10 & 0.0418 & 5.1604 & 0.0051 & 4.6444 & 4.6472 & 18.5888 \\
\hline 15 & 0.0614 & 7.5802 & 0.0075 & 6.8222 & 6.8273 & 27.3095 \\
\hline 20 & 0.0877 & 10.827 & 0.0108 & 9.7444 & 9.7520 & 39.0080 \\
\hline 25 & 0.1102 & 13.604 & 0.0136 & 12.2444 & 12.2552 & 49.0210 \\
\hline 30 & 0.127 & 15.679 & 0.0156 & 14.1111 & 14.1247 & 56.4988 \\
\hline 35 & 0.151 & 18.641 & 0.0186 & 16.7777 & 16.7934 & 67.1738 \\
\hline 40 & 0.174 & 21.481 & 0.0214 & 19.3333 & 19.3519 & 77.4079 \\
\hline 45 & 0.196 & 24.197 & 0.0241 & 21.7777 & 21.7992 & 87.1970 \\
\hline 50 & 0.2187 & 27.111 & 0.027 & 24.3211 & 24.3241 & 97.2967 \\
\hline
\end{tabular}

Table 10: In vitro dissolution study data for vertigon

\begin{tabular}{|c|c|c|c|c|c|c|}
\hline Time (min) & Absorb (205 nm) & Conc. $(\mu \mathrm{g} / \mathrm{ml})$ & Amt. in $1 \mathrm{ml}$ & Amt. in $900 \mathrm{ml}$ & Cumulative release & $\%$ Cumulative drug release \\
\hline 0 & 0 & 0 & 0 & 0 & 0 & 0 \\
\hline 5 & 0.0298 & 3.6790 & 0.0036 & 3.3111 & 3.311 & 13.2444 \\
\hline 10 & 0.0486 & 6.0000 & 0.006 & 5.4221 & 5.403 & 21.6147 \\
\hline 15 & 0.0672 & 8.2962 & 0.0082 & 7.4666 & 7.472 & 29.8906 \\
\hline 20 & 0.0865 & 10.679 & 0.0106 & 9.6111 & 9.619 & 38.4776 \\
\hline 25 & 0.1106 & 13.654 & 0.0136 & 12.288 & 12.29 & 49.1982 \\
\hline 30 & 0.1369 & 16.901 & 0.0169 & 15.211 & 15.22 & 60.8990 \\
\hline 40 & 0.1813 & 22.382 & 0.0223 & 20.144 & 20.164 & 80.6576 \\
\hline 45 & 0.2064 & 25.481 & 0.0254 & 22.933 & 22.955 & 91.8228 \\
\hline 50 & 0.2194 & 27.086 & 0.0270 & 24.377 & 24.403 & 97.6130 \\
\hline
\end{tabular}

Table 11: In vitro dissolution study data for cinnarizine

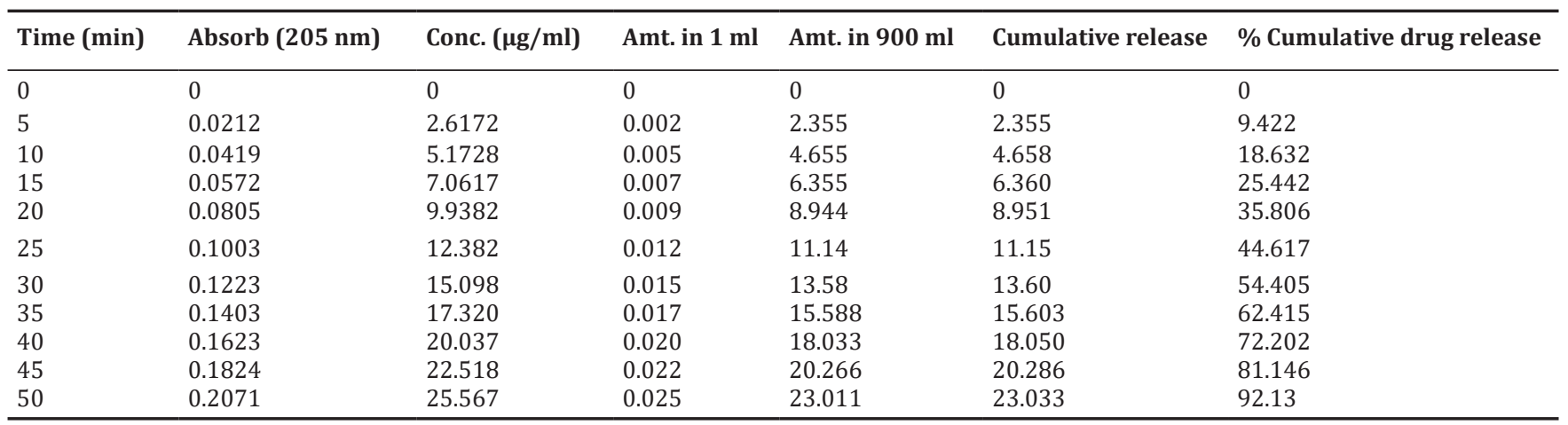




\section{Melting point}

The melting point of cinnarizine was determined by the capillary method using the melting point apparatus (MEPA, LABINDIA).

FTIR results: The spectra are shown in Fig. 1 and characteristic peaks are given in Table 3 .

\section{Loss on drying}

Loss on drying of cinnarizine was found $0.0198 \%$.

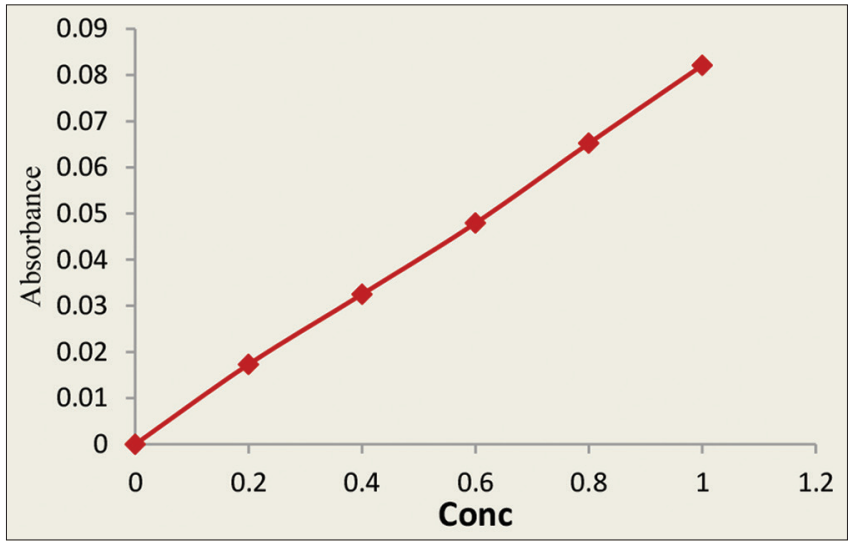

Fig. 3: Calibration curve for cinnarizine

\section{Assay of cinnarizine}

The spectrum of the drug is shown in Fig. 2 and the value of $\lambda_{\max }$ was found to be $205.0 \mathrm{~nm}$.

\section{Calibration curve of cinnarizine}

Nearly $10 \mathrm{mg}$ of cinnarizine was dissolved in $100 \mathrm{ml}$ ethanol in a volumetric flask (stock solution I). From stock solution I, $10 \mathrm{ml}$ solution was taken and the volume was made $(100 \mathrm{ml})$ with ethanol (stock solution II). From stock solution II, aliquots of $0.2,0.4,0.6,0.8$, and $1.0 \mathrm{ml}$ solution were drawn and transferred to $50 \mathrm{ml}$ volumetric flasks and finally, the volume was made up to the mark. UV absorbance was noted at $205 \mathrm{~nm}$ using ethanol as blank.

\section{Solubility studies of drug}

The results were interpreted as practically insoluble, freely soluble, or soluble and shown in Table 5.

The partition coefficient as per the calculations was found to be 2.139 .

Comparative study and evaluation of the concerned drugs and the brand nature of drug and amount are given as under.

\begin{tabular}{lllll}
\hline Tab & Tab & Tab & Tab & Tab \\
\hline Stugeron & Vertigon & Cinzan & Sinarzine & Cinnifit \\
$(25 \mathrm{mg})$ & $(25 \mathrm{mg})$ & $(25 \mathrm{mg})$ & $(25 \mathrm{mg})$ & $(25 \mathrm{mg})$ \\
\hline
\end{tabular}

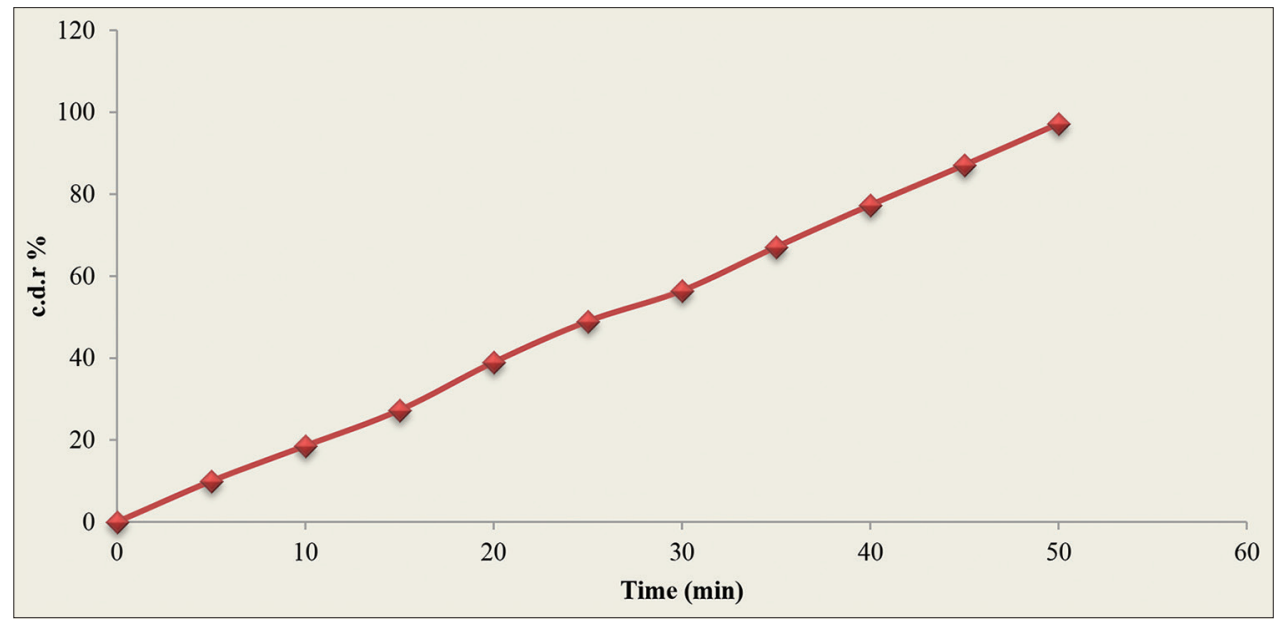

Fig. 4: In vitro dissolution study curve for stugeron at $205 \mathrm{~nm}$

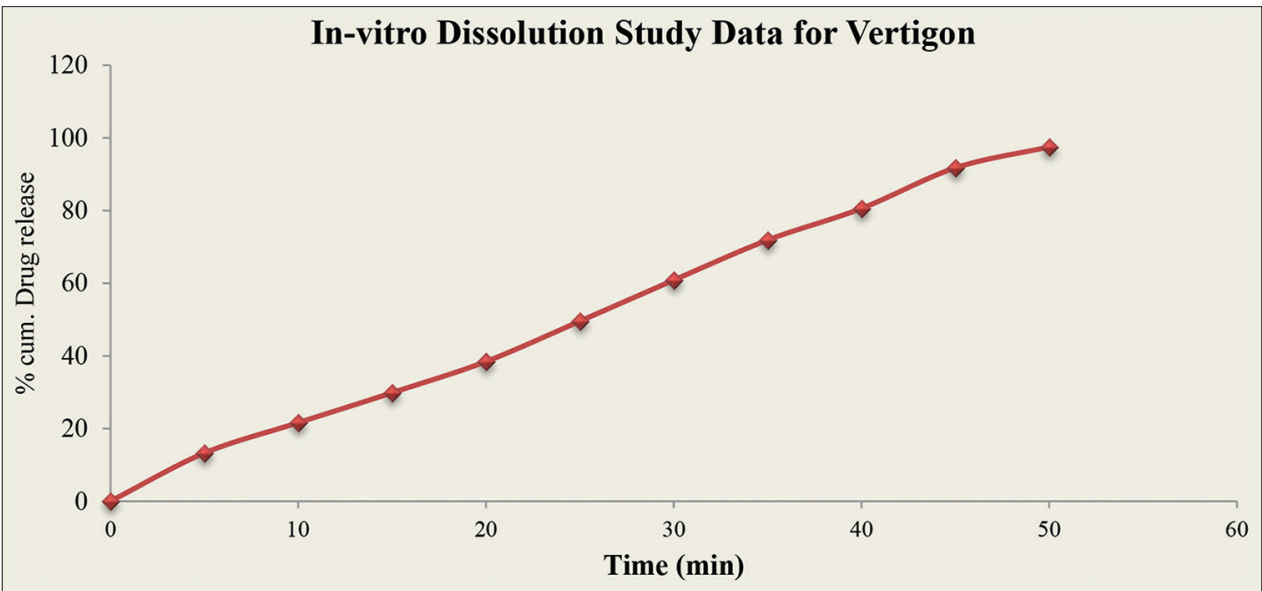

Fig. 5: In vitro dissolution curve for vertigon tablet at $205 \mathrm{~nm}$ 


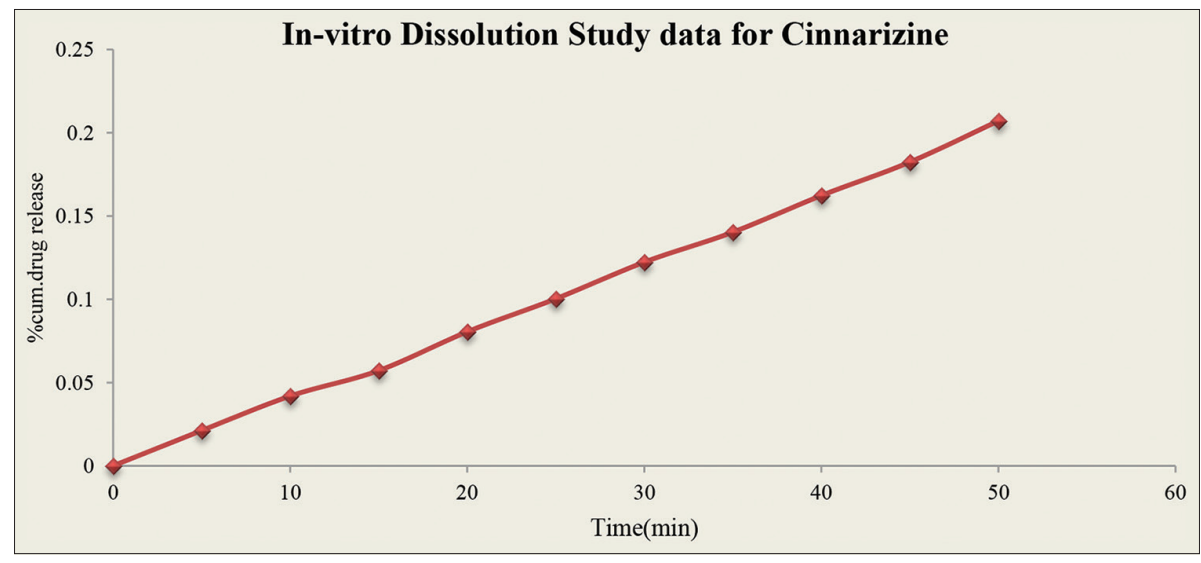

Fig. 6: In vitro dissolution curve of cinzan tablet at $205 \mathrm{~nm}$

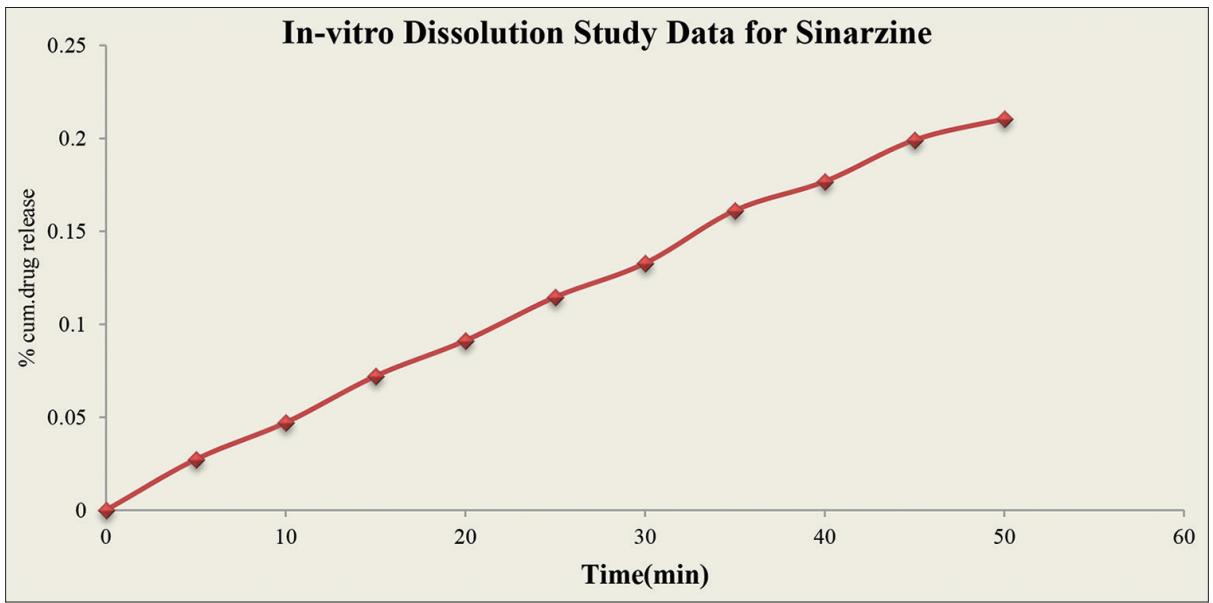

Fig. 7: In vitro dissolution curve of sinarzine tablet at $205 \mathrm{~nm}$

Table 12: In vitro dissolution study data for sinarzine

\begin{tabular}{lllllll}
\hline Time ( $\mathbf{m i n})$ & Absorb $\mathbf{( 2 0 5} \mathbf{~ n m})$ & Conc. $(\boldsymbol{\mu g} / \mathbf{m l})$ & Amt. in $\mathbf{1} \mathbf{~ m l}$ & Amt. in $\mathbf{9 0 0} \mathbf{~ m l}$ & Cumulative release & \% Cumulative drug release \\
\hline 0 & 0 & 0 & 0 & 0 & 0 & 0 \\
5 & 0.0273 & 3.370 & 0.003 & 3.033 & 3.033 & 12.133 \\
10 & 0.0471 & 5.814 & 0.005 & 5.233 & 5.236 & 20.946 \\
15 & 0.0721 & 8.901 & 0.008 & 8.011 & 8.016 & 32.067 \\
20 & 0.0912 & 11.259 & 0.011 & 10.133 & 10.14 & 40.568 \\
25 & 0.1146 & 14.148 & 0.014 & 12.733 & 12.744 & 50.978 \\
30 & 0.1328 & 16.395 & 0.016 & 14.755 & 14.76 & 71.710 \\
35 & 0.1612 & 19.901 & 0.019 & 17.911 & 17.927 & 78.657 \\
40 & 0.1768 & 21.827 & 0.021 & 19.644 & 19.664 & 88.576 \\
45 & 0.1991 & 24.580 & 0.024 & 22.122 & 22.144 & 93.650 \\
50 & 0.2105 & 25.987 & 0.025 & 23.388 & 23.413 & \\
\hline
\end{tabular}

Table 13: In vitro dissolution study data for cinnifit

\begin{tabular}{lllllll}
\hline Time ( $\mathbf{m i n})$ & Absorb $(\mathbf{2 0 5} \mathbf{~ n m})$ & Conc. $(\boldsymbol{\mu g} / \mathbf{m l})$ & Amt. in $\mathbf{1} \mathbf{~ m l}$ & Amt. in $\mathbf{9 0 0} \mathbf{~ m l}$ & Cumulative release & Cumulative drug release $\%$ \\
\hline 0 & 0 & 0 & 0 & 0 & 0 & 0 \\
5 & 0.0229 & 2.8271 & 0.002 & 2.544 & 2.544 & 10.177 \\
10 & 0.0462 & 5.7037 & 0.005 & 5.133 & 5.136 & 20.533 \\
15 & 0.0632 & 7.8024 & 0.007 & 7.022 & 7.027 & 28.088 \\
20 & 0.0868 & 10.7160 & 0.010 & 9.644 & 9.652 & 38.577 \\
25 & 0.1058 & 13.0617 & 0.013 & 11.75 & 11.76 & 57.022 \\
30 & 0.1242 & 15.3333 & 0.015 & 13.8 & 13.81 & 63.466 \\
35 & 0.1428 & 17.6296 & 0.017 & 15.86 & 15.88 & 73.688 \\
40 & 0.1658 & 20.4691 & 0.020 & 18.422 & 18.43 & 86.711 \\
45 & 0.1951 & 24.0864 & 0.024 & 21.677 & 21.698 & 97.866 \\
50 & 0.2202 & 27.1851 & 0.027 & 24.466 & 24.490 & \\
\hline
\end{tabular}




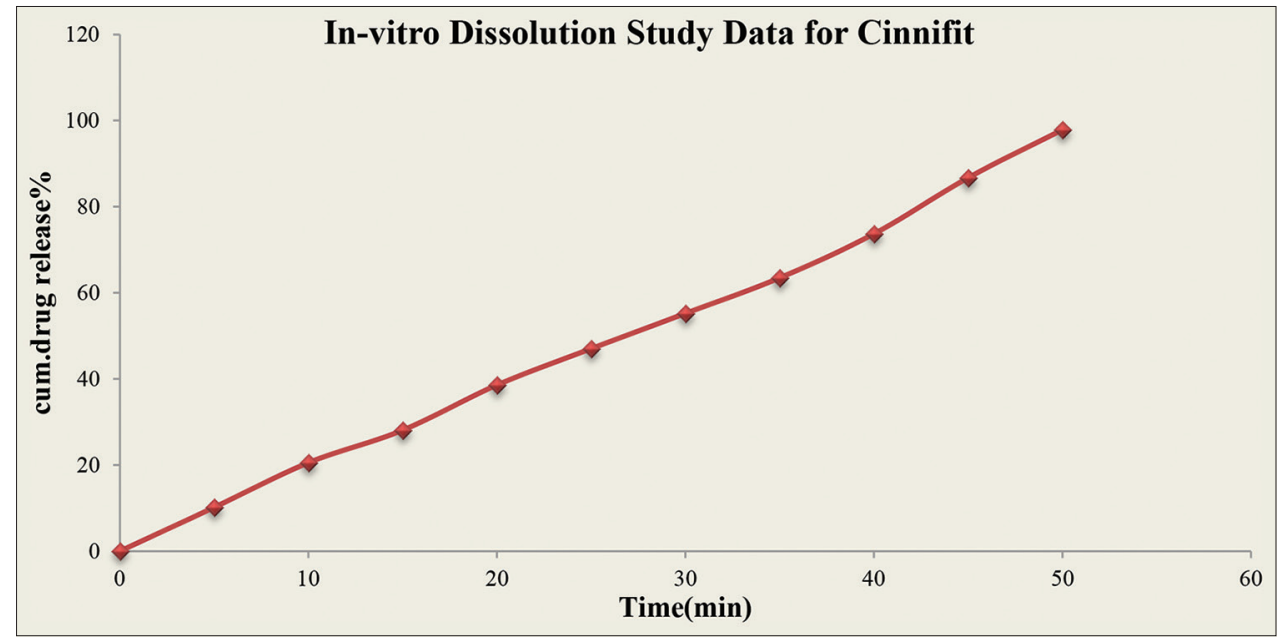

Fig. 8: In vitro dissolution curve of cinnifit tablet at $205 \mathrm{~nm}$

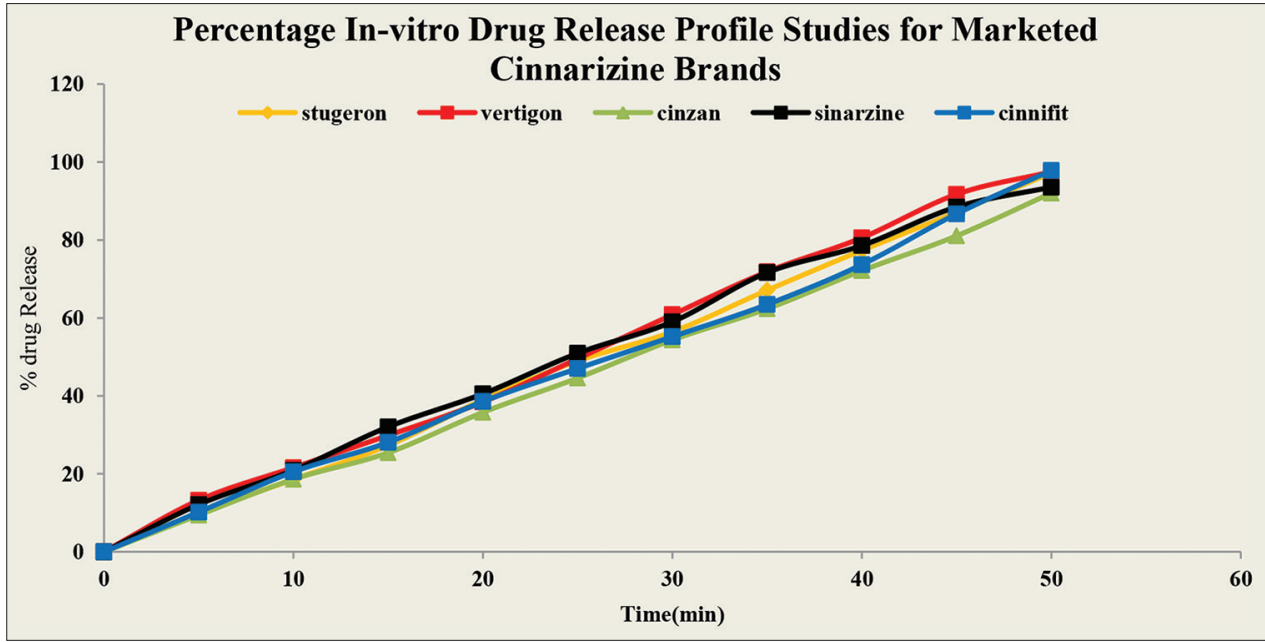

Fig. 9: In vitro release profile of all marketed formulations

Table 14: Pre-formulation studies

\begin{tabular}{llll}
\hline S. No. & Parameters & Observation & Inference \\
\hline 1. & Color & Crystalline white & Confirms to \\
2. & Melting point & $117^{\circ} \mathrm{C}$ & reference \\
3. & FTIR & $\mathrm{C}-\mathrm{H}, \mathrm{C}=\mathrm{C}, \mathrm{C}-\mathrm{N}, \mathrm{N}-\mathrm{H}$ & standards \\
4. & Loss on drying & $0.0198 \%$ & \\
5. & Assay & $205.0 \mathrm{~nm}$, slope 0.081 & \\
6. & Solubility & Di-ethyl ether & \\
7. & Partition coefficient & 2.139 & \\
\hline
\end{tabular}

The evaluation parameters which have been carried out include uniformity of weight, determination of tablet hardness, drug content uniformity, friability of tablet, determination of disintegration time, and in vitro dissolution study.

\section{Uniformity of weight [7]}

Twenty tablets were selected randomly from each batch and were weighed accurately, and the average weight was calculated, and the deviation of individual weights from the average weight and the standard deviation was calculated.

The weight variation limits are within the range of acceptability as the deviation percentage is 10 for $80 \mathrm{mg}$ tablet, 7.5 for $80 \mathrm{mg}$ to $250 \mathrm{mg}$, and 5 for $250 \mathrm{mg}$ tablets.
Determination of tablet hardness

The average hardness and standard deviation were calculated and the results are as.

\section{Determination of friability of the tablet}

The friability value of the uncoated tablets was found to be as stugeron $-0.4 \%$, vertigon $-0.0 \%$ cinzan $-0.5 \%$, sinarzine $-0.0 \%$, and cinnifit $0.0 \%$.

\section{Determination of disintegration time [7]}

In vitro disintegration time of six tablets from each of the formulation was determined using a digital tablet disintegration apparatus. In vitro disintegration was carried out (at $\left.37 \pm 2^{\circ} \mathrm{C}\right)$ in $900 \mathrm{ml}(0.1 \mathrm{~N})$ hydrochloric acid buffer and the observed results are as.

\begin{tabular}{llllll}
\hline Drug & Stugeron & Vertigon & Cinzan & Sinarzine & Cinnifit \\
\hline Time & $90 \mathrm{~s}$ & $15 \mathrm{~s}$ & $29 \mathrm{~s}$ & $17 \mathrm{~s}$ & $5 \mathrm{~s}$ \\
\hline
\end{tabular}

\section{DISCUSSION}

The result of pre-formulation study is shown in the above table [8], which are very closely to the actual and standard values of different preformulation studies of the pure cinnarizine API. The pre-formulation study of any drug is a very important tool for further investigation of the sample. The pre-formulation study of cinnarizine API is very useful for the further evaluation parameters of the tablets. 
Table 15: Pre-formulation studies of cinnarizine tablet

\begin{tabular}{llllll}
\hline Formulation $\mathbf{2 5} \mathbf{~ m g})$ & Weight variation $\mathbf{( m g )}$ & Hardness $\mathbf{( k g})$ & Drug content $\mathbf{( \% )}$ & Friability (\%) & Disintegration time (s) \\
\hline Stugeron & $0.245 \pm 0.0245$ & 2.0 & 96.23 & 0.4 & 90 \\
Vertigon & $0.121 \pm 0.0121$ & 0.0 & 99.54 & 0.0 & 15 \\
Cinzan & $0.176 \pm 0.0176$ & 4.0 & 98.57 & 0.5 & 29 \\
Sinarzine & $0.187 \pm 0.0187$ & 0.8 & 97.01 & 0.0 & 17 \\
Cinnifit & $0.205 \pm 0.0205$ & 0.2 & 99.80 & 0.0 & 5 \\
\hline
\end{tabular}

Table 16: Percentage drugs release profile studies for cinnarizine brands

\begin{tabular}{lllllll}
\hline S. No. & Time (min) & \multicolumn{6}{l}{ Cumulative drug release \% } \\
\cline { 3 - 7 } & & Stugeron (25 $\mathbf{~ m g})$ & Vertigon $\mathbf{2 5} \mathbf{~ m g )}$ & Cinzan $\mathbf{( 2 5} \mathbf{~ m g})$ & Sinarzine (25mg) & Cinnifit (25 mg) \\
\hline 1. & 5 & 9.955 & 13.24 & 9.422 & 12.133 & 10.17 \\
2. & 10 & 18.577 & 21.6 & 18.622 & 20.933 & 20.53 \\
3. & 15 & 27.288 & 29.86 & 25.422 & 32.044 & 28.08 \\
4. & 20 & 38.977 & 38.44 & 35.777 & 40.533 & 38.57 \\
5. & 25 & 48.977 & 49.54 & 44.577 & 50.933 & 47.02 \\
6. & 30 & 56.444 & 60.84 & 54.355 & 59.022 & 63.4 \\
7. & 35 & 67.111 & 71.86 & 62.355 & 71.644 & 73.68 \\
8. & 40 & 77.333 & 80.57 & 72.133 & 78.577 & 86.71 \\
9. & 45 & 87.111 & 91.73 & 81.066 & 88.488 & 97.86 \\
10. & 50 & 97.20 & 97.51 & 92.044 & 93.555 & \\
\hline
\end{tabular}

All brand's tablets were evaluated for the determination of weight variation; hardness; drug content; friability; disintegration; and dissolution. After evaluation, the different parameters were determined successfully and the resulted value of different parameters is shown in the given table [9], respectively.

The comparative dissolution study of the various marketed formulation was carried out. The release profile of all brand's tablets is shown in the given Table 4.3. The release of drug was shown as \% cumulative drug release (\%CDR) with respect to a time interval (minutes). The resulted graph was shown below to describe the in vitro drug release of all brand's tablets.

The in vitro drug release kinetics of all marketed tablets were shown in Figure 9. All marketed tablets release the drug in a good manner. The \%CDR was found as $97.20,97.51,92.04,93.55$, and 97.86 for the stugeron, vertigon, cinzan, sinarzine, and cinnifit, respectively. The maximum drug release was found for cinnifit marketed formulation.

\section{CONCLUSION}

The study was conducted to determine different evaluation parameters as well as the drug release kinetics of the tablets in relation to consider the five concerned tablets as bioequivalent. In the study, it had been concluded that all brand tablets are of good quality. The tablets after evaluation for different parameters meet the standard acceptance criteria. All the tablets show acceptable limits for weight variation and hardness, and all tablets show efficient drug release in a sustained release manner. Thus, it can be concluded that all the tablets are effective for usage under standard conditions.

\section{REFERENCES}

1. Li S. Biodegradable polymers: Polyesters. In: Mathiowitz E, editor. Encyclopedia of Controlled Drug Delivery. New York: John Willey and Sons Inc.; 1999. p. 71-3.

2. Streubel A. Drug Delivery to the upper small intestine window using gastroretentive technologies. Curr Opin Pharmacol 2006;6:501-8.

3. Lachman L, Lieberman HA, Kanig JL. The Theory and Practice of Industrial Pharmacy. $3^{\text {rd }}$ ed. Dadar, Bombay: Varghese Publishing House Hind Rajasthan Building; 1987. p. 400014.

4. Kesharvani S, Jaiswal PK, Mukerjee A, Singh AK. Formulation and evaluation of metformin hydrochloride loaded floating microspheres. Int J Pharm Pharm Sci 2019;12:74-82.

5. Patel M, Patel NV, Patel TB. Design and development of rilpivirine nanoparticle containg chitosan using ionic gelation method for HIV infections. Int J Pharm Pharm Sci 2020;12:113-8.

6. Ministry of Health and Family Welfare. Indian Pharmacopoeia. Vol. 2. India: Government of India, Ministry of Health and Family Welfare; 2010. p. 187-95.

7. Lieberman L, Herbert A, Lachmann L, Schwartz J. Pharmaceutical Dosage Forms: Tablets. Vol. 1. New York: Marcel Dekker; 2005. p. 1-69.

8. Halakatti P. Development of mouth dissolving tablets of cinnarizine. Int J Pharm Sci 2010;2:631-40.

9. Ringard J, Hermann AM. Calculation of disintegrant critical conc. In order to optimize tablet disintegration. Drug Dev Ind Pharm 1997;14:2321-39. 